over peritoneal dialysis. Correction of the metabolic state, control of convulsions and maintenance of oxygenation and hydration appear to be the most important aspects of therapy.

Poisoning by salt emetics is particularly regrettable as other methods of inducing vomiting exist. Syrup of ipecacuanha has been used extensively in paediatric practice with no reported adverse effect and many patients can be made to vomit by pharyngeal stimulation. Salt usually induces vomiting even in small quantities but the amounts and dilutions recommended in first aid books vary widely and the recipes are often vague. In our view, either the recommendation of the use of salt emetics should be abandoned, or very strict warning given of the danger of overdose.

\section{Acknowledgment}

We are grateful to $\operatorname{Dr}$ A. C. Hunt for supplying details of the necropsy and for his helpful advice, and to Dr G. R. Steed for allowing us to report a patient under his care.

\section{References}

Cameron, J.M. \& Dayan, A.D. (1966) Association of brain damage with therapeutic abortion induced by amnioticfluid-replacement. Report of two cases. British Medical Journal, 1, 1010.

Dayan, A.D., Cameron, M.M. \& Phillipp, E. (1967) Fatal brain damage associated with therapeutic abortion induced by amniocentesis. Report of one case. Medicine, Science and Law, 7, 70.

DeGenaro, F. \& Nyhan, W.L. (1971) Salt-a dangerous 'antidote'. Journal of Pediatrics, 78, 1048.

Elton, N.W., Elton, W.J. \& Nazareno, J.P. (1963) Pathology of acute salt poisoning in infants. American Journal of Clinical Pathology, 39, 252.

Finberg, L., Kiley, J. \& Luttrell, C.N. (1963) Mass accidental salt poisoning in infancy. Journal of the American Medical Association, 184, 187.

LAURENCE, B.H. \& HoPKINS, B.E. (1969) Hypernatraemia following a saline emetic. Medical Journal of Australia, 1, 1301.

ROBERTSON, W.O. (1971) A further warning on the use of salt as an emetic agent. Journal of Pediatrics, 79, 877.

WARD, D.J. (1963) Fatal hypernatraemia after a saline emetic. British Medical Journal, 2, 432.

\title{
Acute ethanol poisoning treated by haemodialysis
}

\author{
R. W. ElliotT \\ M.D., M.R.C.P. \\ P. R. HUNTER \\ M.A., M.R.C.P. \\ University Department of Medicine, Royal Victoria Infirmary, Newcastle upon Tyne NE1 4LP
}

\begin{abstract}
Summary
A non-alcoholic patient with severe ethanol poisoning who was deteriorating clinically despite adequate supportive therapy was successfully treated by haemodialysis.
\end{abstract}

\section{Case history}

A 23-year-old man was admitted at 7 p.m. Since the morning he had drunk 10 pints of beer. He was then 'dared' to drink half a bottle of gin, which he did quickly. At 5 p.m. he suddenly fell unconscious to the floor.

On examination. There were superficial abrasions over the anterior chest wall and right temple sustained when he fell. Respiration rate was $20 / \mathrm{min}$ with adequate ventilation of both lungs, pulse 132 , B.P. $140 / 80 \mathrm{mmHg}$, heart sounds normal. He was unrousable and unresponsive to painful stimuli. Limb reflexes were brisk and equal. Pupils were equal and reacted to light. He was intubated with a cuffed endotracheal tube and his stomach washed out.

Biochemical tests on admission showed blood ethanol $465 \mathrm{mg} \%$, blood sugar $93 \mathrm{mg} \%$, plasma urea and electrolytes normal. Arterial $\mathrm{pH} 7 \cdot 27$, actual $\mathrm{PCO}_{2} 35 \mathrm{mmHg}$, base excess $10 \mathrm{mEq} / \mathrm{l}$, buffer base $38 \mathrm{mEq} / \mathrm{l}$, standard bicarbonate $17 \mathrm{mEq} / \mathrm{l}$, actual bicarbonate $15 \mathrm{mEq} / \mathrm{l}$, indicating a moderate metabolic acidosis.

Over the next $2 \mathrm{hr}$ his condition deteriorated. The pupils became widely dilated and unresponsive to light. The limb reflexes became unobtainable. Respiration slowed and became more shallow. Blood pressure fell to $90 / 60 \mathrm{mmHg}$, but peripheral perfusion remained satisfactory. This depression of the central nervous system could not be attributed to hypoventilation as at this time an arterial $\mathrm{Po}_{2}$ was $91 \mathrm{mmHg}$, and the $\mathrm{PCO}_{2}$ was $25 \mathrm{mmHg}$.

Because of this clinical deterioration and his 
dangerously high blood ethanol level, it was decided to treat him by haemodialysis.

A Scribner shunt was inserted and haemodialysis performed using a modified Kolff Twin-coil artificial kidney with a 2501 recirculating reservoir, a Travenol Ultrafio 100 Cellophane coil and a dialysate composition of $\mathrm{Na} 133 \mathrm{mEq} / \mathrm{l}, \mathrm{K} 3.3 \mathrm{mEq} / \mathrm{l}$, and glucose $2 \%$. Two hundred millilitres of saline were given hourly to prevent dehydration.

After $2 \mathrm{hr}$ dialysis the blood pressure had risen to $120 / 80 \mathrm{mmHg}$ and the pulse had settled to $100 / \mathrm{min}$.

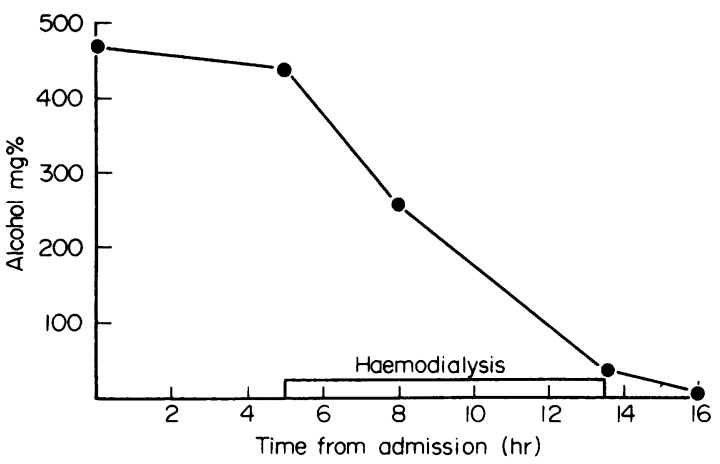

Fig. 1. Blood ethanol levels.

At the commencement of dialysis the ethanol level was $440 \mathrm{mg} \%$ and by $3 \mathrm{hr}$ it had fallen to $255 \mathrm{mg} \%$ (Fig. 1), an average fall of $62 \mathrm{mg} \% / \mathrm{hr}$. At this time the arterio-venous difference across the artificial kidney was $112 \mathrm{mg} \%$. The blood flow rate was $250 \mathrm{ml} / \mathrm{min}$, giving a clearance of $110 \mathrm{ml} / \mathrm{min}$ and a removal rate of $280 \mathrm{mg}$ of ethanol $/ \mathrm{min}$.

Dialysis was continued for $8 \frac{1}{2} \mathrm{hr}$ and the patient made a complete recovery without a hangover. He was discharged from hospital the following day.

\section{Discussion}

Acute alcoholic poisoning is infrequently a direct cause of death. If large quantities are taken rapidly, especially when the level is already high, fatal concentrations may be attained. Ethanol levels in excess of $350 \mathrm{mg} \%$ are considered to be dangerous (Walls and Brownlie, 1970a) and over $500 \mathrm{mg} \%$ fatal (Kaye and Haag, 1957). In most cases death is due to the direct effect of ethanol on the brain causing either respiratory arrest or coma with aspiration of vomit. However, these are not the sole causes of death in cases of acute alcoholic poisoning. Sudden unexplained deaths occur when the blood alcohol level is falling. It is possible that these are cardiac in origin when one considers that a sinus tachycardia is a constant feature of the condition and that in heavy drinkers sudden death can occur owing to the toxic effect of ethanol on the myocardium (Laurie, 1971). There would seem to be a case, therefore, in severely poisoned patients, for trying to reduce blood alcohol levels rapidly.

Ethanol fulfils the criteria for a dialysable poison (Schreiner, 1958) in that it has a low mol. wt. of 46, is not bound to protein in the body and crosses a cellophane membrane readily. Only $5 \%$ is excreted in the urine unchanged and forced diuresis plays little part in the total excretion.

The liver is the major site of elimination and is responsible for reducing the blood level by a fairly constant $15 \mathrm{mg} \% / \mathrm{hr}$ (Walls and Brownlie, 1970b). Marc Aurele and Schreiner (1960) showed that in dogs the elimination of alcohol could be increased fourfold by haemodialysis and this has since been substantiated by Walder et al. (1969) dialysing acutely intoxicated chronic alcoholics.

The depletion in ethanol poisoning of hepatic coenzyme DPH involved in both the oxidation of ethanol and gluconeogenesis may result in hypoglycaemia (Sodeman and Sodeman, 1967). This effect may be severe enough to cause typical hypoglycaemic symptoms and even coma. In the present case the blood sugar was normal at the beginning of dialysis and a fall was prevented by the $2 \%$ glucose in the dialysate. A level taken at $3 \mathrm{hr}$ was $275 \mathrm{mg} \%$.

In a recent controlled series (Brown, Forrest and Roscoe, 1972) it was shown that the intravenous infusion of $200 \mathrm{~g}$ of fructose over a period of $30 \mathrm{~min}$ increased the rate of fall of blood ethanol from 22.5 $\mathrm{mg} \% / \mathrm{hr}$ in the controls to $27.6 \mathrm{mg} \% / \mathrm{hr}$ in treated cases. This represents an overall increase in elimination of ethanol of $25 \%$, but the effect is variable and inadequate in treating a severe case who may suffer prolonged coma. In a report by Yacoub et al. (1973) a patient with an initial level of $630 \mathrm{mg} \%$ remained comatose for $72 \mathrm{hr}$ when only supportive therapy was used. Haemodialysis is a more effective and reliable treatment. In the present case a fall of only $5 \mathrm{mg} \% / \mathrm{hr}$ was observed in the $5 \mathrm{hr}$ between admission and commencement of dialysis. This would suggest that the peak level occurred between these two estimations and probably accounts for clinical deterioration. During the first $3 \mathrm{hr}$ of dialysis a fall of approximately $62 \mathrm{mg} \% / \mathrm{hr}$ was achieved; this is $280 \%$ greater than the control series studied by Brown et al. (1972) which included some alcoholics, and $360 \%$ greater than normal controls quoted by Patel et al. (1969).

It is therefore recommended that haemodialysis should be considered as a method of treatment in a severe case of ethanol intoxication who is showing clinical deterioration.

\section{References}

Aurele, M.J. \& Schreiner, G.E. (1960) The dialysance of ethanol and methanol: a proposed method for the treatment of massive intoxication by ethyl or methyl alcohol. Journal of clinical Investigation, 39, 802. 
Brown, S.S., Forrest, J.A.H. \& Roscoe, P. (1972) A controlled trial of fructose in the treatment of acute alcoholic intoxication. Lancet, ii, 898.

KAYE, S. \& HAAG, H.B. (1957) Terminal blood alcohol concentrations in ninety-four fatal cases of acute alcoholism. Journal of the American Medical Association, 165, 451.

LAURIE, W. (1971) Alcohol as a cause of sudden unexpected death. Medical Journal of Australia, 1, 1224.

Patel, A.R., Paton, A.M., Rowan, T., Lawson, D.H. \& Linton, A.L. (1969) Clinical studies on the effect of laevulose on the rate of metabolism of ethyl alcohol. Scottish Medical Journal, 14, 268.

SCHREINER, G.E. (1958) The role of haemodialysis (artificial kidney) in acute poisoning. Archives of Internal Medicine, 102, 896.
Sodeman, W.E. \& Sodeman, W.E., JR (1967) Pathologic Physiology. W. B. Saunders, Philadelphia and London, p. 106.

Walder, A.I., Reddings, J.S., Faillace, L., Steenburg, R.W. (1969) Rapid de-toxification of the acute alcoholic with haemodialysis. Surgery, 66, 201.

Walls, H.J. \& Brownlie, A.R. (1970a) Drink, Drugs and Driving. Sweet and Maxwell, London, p. 38.

Walls, H.J. \& Brownlie, A.R. (1970b) Drink, Drugs and Driving. Sweet and Maxwell, London, p. 17.

Yacoub, M., Mobena, H., Faure, J. \& Mallion, J.M. (1973) Évolution de l'alcoolémie après ingestion massive d'alcool. Bulletin Médical Légal et Toxicologique, 16, No. 6, 447.

\section{Coma following treatment of very severe arterial hypertension, with improvement after dexamethasone therapy}

\author{
L. J. FARROW \\ M.D., M.R.C.P.
}

\author{
J. B. WoOD \\ B.M., M.R.C.P.
}

Division of Medicine, St Mary's Hospital, London W.2

\section{Summary}

We describe two patients with very severe arterial hypertension, who were treated vigorously and effectively with hypotensive drugs. Both promptly developed gross neurological abnormalities, yet recovered fully after treatment with dexamethasone. We have found no similar published reports. We believe that these cases illustrate an important risk of treatment of severe hypertension, and we suggest that cerebral oedema developed, and was then relieved by dexamethasone.

\section{Introduction}

The autoregulation of the cerebral circulation results in a constant cerebral blood flow despite wide fluctuations in arterial pressure. At very high pressure this autoregulation is overwhelmed and cerebral blood flow increases, and at very low pressures autoregulation fails and blood flow diminishes (Strandgaard et al., 1973). In arterial hypertension, autoregulation persists, but functions over a higher range of blood pressures than normal. In a group of severely hypertensive patients, Strandgaard et al. (1973) showed that autoregulation broke down when the mean arterial pressure fell abruptly to $120 \mathrm{mmHg}$,

Requests for reprints: Dr J. B. Wood, County Hospital, Hereford HR1 2ER. and dizziness due to cerebral hypoxia occurred when the mean arterial pressure fell to about $70 \mathrm{mmHg}$, in contrast to normotensive subjects who could tolerate much lower pressures. Vigorous treatment of hypertension may, therefore, lead to cerebral hypoxia if the blood pressure falls too far. Fazekas (1966) recommended that the diastolic pressure should only be brought rapidly to $110 \mathrm{mmHg}$, and that further reduction should be gradual to allow time for the cerebral circulation to adjust to the lower pressure. Most articles and textbooks do not give specific advice about this, or describe what happens if treatment is too effective.

\section{Case 1}

A 44-year-old West Indian woman had a 2-year history of very severe untreated hypertension of unknown cause, and developed headache, drowsiness and left-sided weakness. Gross papilloedema, Cheyne-Stokes respiration and blood pressure of $230 / 160 \mathrm{mmHg}$ were found. She was treated with pentolinium, guanethidine, diazoxide and intravenous mannitol, and her diastolic pressure fell to between 70 and $110 \mathrm{mmHg}$. Within $12 \mathrm{hr}$ she became drowsy, with weakness of the right arm and face, and then became comatose, with fixed dilated pupils, a stiff neck and fresh retinal haemorrhages. 